\title{
NATIONAL PROJECT MANAGEMENT MATURITY: A CONCEPTUAL FRAMEWORK
}

\author{
Seelhofer, D., Graf, C. 0.
}

This paper extends the concept of organizational project management maturity to the national context. Based on a review of the extant literature and a thorough analysis of existing organizational maturity models, it develops a systematic framework of national project management maturity and the national project management maturity model (NPM3), by defining maturity levels, identifying key maturity perspectives and drivers, and discussing key performance indicators that may be used to assess and compare national project management maturity. Practical implications, limitations, and the need for further research are discussed.

Keywords: project management; maturity

JEL Classification: L20, L78, M10

\section{Introduction}

Organizations profit from competent project management, which can be a significant organizational success factor (see e.g. Pinto and Prescott, 1988; Shenhar, Levy and Dvir, 1997; Milosevic, 2003; Srivannaboon, 2009; Lundin and Hällgren, 2014). The two large international project management associations, the U.S.-based Project Management Institute (PMI) and the Europe-based International Project Management Association (IPMA) have both experienced substantial growth in recent years, and according to KPMG's 2017 Project Management Survey the significance of organizational project management is expected to increase further in the coming years.

Competent project management, therefore, is clearly relevant. Yet according to the Standish Group's Chaos Report, which has been published every year since 1994, about two thirds of all projects fail (Standish Group, 2018). And the Project Management Institute estimates that around $12 \%$ of all investments are wasted due to poor project performance (PMI, 2016). This clearly has far-reaching economic implications. Yet despite these numbers, the wider public generally only realizes the importance of project management competencies when failures of large public projects become known. As Kreiner (2014, p. 20) puts it: "[...] but in short it is failure, not success, that dominates the narratives of projects and their management." In the United Kingdom, for example, the 
Ministry of Defence's Defence Information Infrastructure project (a defense computer system designed to help Britain's troops operate more effectively on deployment abroad), the National Health Service's National Programme for IT (a centralized electronic care record system that would have connected about 30,000 general practitioners to more than 300 hospitals) or the Scottish parliament building (which opened three years late and ran about ten-fold over budget) have all become synonymous with failed public projects. In another large developed economy, Germany, famous examples include the Flughafen Berlin Brandenburg project to build a new international airport in Berlin, which is expected to be about ten years behind schedule and at least four times over budget when it finally opens. In another German case, Stuttgart 21, a new underground central train station in Stuttgart will be at least 6 years behind schedule and is expected to exceed its original budget by a factor of at least four; or the Elbphilharmonie, a new concert hall in Hamburg that was almost seven years late when it opened in 2017 and cost more than 11 times the originally planned amount. These examples may be surprising, considering that both countries have a good project management reputation and active project management bodies. In the United Kingdom, the PMI's local Chapter has around 3,500 members, while the IPMA's local certification body, the Association for Project Management (APM), counts more than 23,000 members. The IPMA's German chapter, the Deutsche Gesellschaft für Projektmanagement (German Association for Project Management, GPM), also has around 8,000 members. Yet large-scale project failures continue to happen, and governments should take an active role in combating this. The United States, for example, have continuously emphasized the importance of project management at the government level after having won the Space Race of the 1960s - due to its, at the time, advanced project management competencies. In line with this, former president Barack Obama signed the Program Management Improvement and Accountability Act in 2016, which was designed to increase accountability and best practices in project management throughout the United States government.

The question, however, is what a country can do to increase project management competence not just at the government level but across the domestic economy, thereby contributing to the agility and national and international success of its domestic firms. A promising conceptual start are project management maturity models that are widely employed at the organizational level but have so far not been extended to the national stage. This paper attempts to start a corresponding discussion by suggesting a framework that can be used to assess national project management maturity (NPMM). 2 Theoretical Framework

\section{Literature Review}

Organizational project management maturity has been described as the organization's openness to project management (Skulmoski, 2001). Project management maturity models provide capability assessment and development frameworks that help organizations 
compare their project delivery and performance to its competitors and/or with best practice and provide a structured path to improvement (Schlichter and Skulmoski, 2000; Hillson, 2001; Foti, 2002). The model's roots lie in the Capability Maturity Model developed between 1986 and 1993 by the Software Engineering Institute (SEI) at Carnegie Mellon University (Grant and Pennypacker, 2006).

One of the most popular maturity models today is the Organizational Project Management Maturity Model (OPM3). The OPM3 program was initiated in 1998 with the aim to develop a standard maturity model. Introduced in 2003, OPM3 is now in its third edition and is widely used. It revolves around three core themes: acquiring knowledge, performing assessment, and managing improvement (PMI, 2013). Based on a large number of best practice examples, organizations are enabled to evaluate their project management capabilities and identify areas that need improvement, which are then dealt with by designing and implementing an appropriate action plan.

Besides OPM3, there is a substantial number of other maturity models. An initial list was presented by Schlichter and Skulmoski (2000), and in 2003 Pennypacker and Grant estimated that there were over 30 project management maturity models in use then. Nonetheless, the usefulness of the maturity concept is not a universally shared view. On one hand, project management maturity is seen as an increasingly important success factor, especially for organizations that deal with a range of projects, programs, and portfolios (Bushuyev and Wagner, 2014) because of a reported link between project management maturity and organizational performance (Torres, 2014). This link has been attributed to the fact that an increased understanding of an organization's capabilities enhances organizational learning and improvement (Mullaly, 2006), that application of the model implies decisions are based on facts rather than intuition and experience (Cooke-Davies and Arzymanow, 2003)Also, such models provide a structured and systematic framework for identifying an organization's project management-related strengths and weaknesses (Backlund et al., 2014), which in turn may contribute to better prioritizing actions and initiating cultural change (Crawford, 2006).

On the other hand, some authors question the link between higher maturity levels and organizational success (e.g. Besner and Hobbs, 2013), while others lament that existing models are too complex for efficient assessments and address only tacit but not implicit project management knowledge (Jugdev and Thomas, 2002; Hillson, 2003).

Despite these comparatively isolated criticisms, however, the concept of project management maturity is by now widely accepted and applied not just at the organizational but also at the industry level. For example, in 1997 Ibbs and Kwak used the Berkeley Project Management Process Maturity model to compare the U.S. engineering and construction, high-tech manufacturing, telecom, and information systems industries with each other and found that, back then, the first three evidenced significantly higher project management maturity than the last but that, overall, maturity was comparatively low across 
the board. In 2006, Grant and Pennypacker used the PM Solutions Project Management Maturity Model to analyze the U.S. manufacturing, information, finance and insurance, and professional/scientific/technical services industries and also found that project management maturity was consistently low in all these industries. In 2011, Ghoddousi, Amini, and Hosseini used the OPM3 to analyze 81 Iranian construction companies and discovered that almost two-thirds of them had a project management maturity of below $50 \%$. In line with the notion of performance benefits of project management maturity, they also found that only companies which showed noticeable maturity levels had been able to win projects based on international tenders.

Other examples where such models were used to analyze industry-wide project management maturity include: the software industry in Estland (Puus and Mets, 2010), the engineering and construction industry in South Africa (Pretorius et al., 2012) and Morocco (Alami et al., 2015), and the Serbian energy sector (Mihic et al., 2015). All these studies found generally low levels of project management maturity. The preliminary results of the OPM3 Portugal Project (Silva et al., 2014) and Backlund et al.'s (2014) case studies of Swedish engineering and construction companies also suggest the same.

From a national perspective, this low level of project management maturity across important industries should be worrisome. If project management maturity is a competitive factor at the organizational level, then the same should be true at the aggregate industry and, by extension, national level. In line with Michael Porter's seminal theory of the competitive advantage of nations, where government plays an important role as a facilitator of advanced factors like infrastructure and education (Porter, 1990), a country should actively foster and improve project management maturity. In fact, various emerging economies have been the subject of early efforts to improve project management capabilities and to identify obstacles to development in an attempt to overcome competitive disadvantages. For example, Kazakhstan organized and hosted the 2017 IPMA World Congress in Astana, welcoming around 1,000 project management professionals from around the world. A study of the impact of project failure on Zimbabwe's socioeconomic development concluded that corruption and other factors like irresponsible government led to a so-called unconducive environment that preceded-and, indeed, promoted-project failure (Mapepeta. 2016). And Ghana (Ofori and Deffor, 2013), Indonesia (Simangunsong and Da Silva, 2013), and Kazakhstan (Narbaev, 2015) were the subjects of early attempts to measure and develop national project management maturity.

Despite these efforts, however, there presently seems to be no holistic framework to assess a country's national project management maturity. 


\section{Methodology}

Reasonably, a framework of national project management maturity should follow the logic and structure of existing organizational maturity models. In order to do so, the most relevant models must first be identified. This was done in a three-step process.

In a first step, a full list of project management maturity models in current use was compiled through a systematic review of the extant project management literature. This led to a list of 36 different models.

In a next step, the academic relevance of these models was determined based on a quantitative and a qualitative criterion. First, the number of citations for the corresponding base articles was retrieved from Google Scholar. The resulting scores where then ranked in descending order and the two lower quartiles excluded, which left 18 models. Second, the remaining models' relevance in the literature was analyzed and rated as low, medium, or high according to how they were discussed. All those rated as low were excluded, which left 11 models.

Finally, the practical relevance of each of the remaining models was assessed by four project management experts. Of these, two were university lecturers in project management. Both represented either a formal focus on project management or a unit with 'project management' in its title. The other two were senior project managers employed in the private sector holding formal project management certification. All had at least 10 years' worth of experience as project managers. Practical relevance was measured as mean score of the individual assessors' subjective evaluation of each model, measured on a scale from zero ('not relevant') to three ('highly relevant'). All models which were rated less than two ('somewhat relevant') were excluded from the final list. This process led to the identification of seven models of current, practical relevance that provided the starting point for the development of a framework of national project management maturity. A basic model of national project management maturity was then derived by systematically comparing and synthesizing these frameworks. Finally, key performance indicators and associated basic assessment rubrics for the model were obtained by collecting and aggregating inputs for each point from the above-mentioned experts.

\section{Results}

The seven models identified as having both current academic and practical relevance are listed in Table 1.

Developed at the Software Engineering Institute at Carnegie Mellon University and first introduced in a technical report in 1987, the Capability Maturity Model Integration (CMMI) was intended to eliminate the need for multiple models during software development by integrating three existing capability maturity models, the Capability Maturity Model for Software SW-CMM, the Systems Engineering Capability Model 
SECM, and the Integrated Product Development Capability Model IPD-CMM (Humphrey, 1988). The CMMI defines five maturity levels and has been applied in the airline, automotive, banking, education, engineering, health care, IT, and telecommunications industries.

Table 1 | Comparison of Existing Project Management Maturity Models

\begin{tabular}{|c|c|c|c|c|}
\hline $\begin{array}{c}\text { Model } \\
\text { (Acronym) }\end{array}$ & $\begin{array}{l}\text { Origin } \\
\text { (Year) }\end{array}$ & Description & Maturity Levels & $\begin{array}{l}\text { Industry } \\
\text { Application }\end{array}$ \\
\hline $\begin{array}{l}\text { Capability } \\
\text { Maturity Model } \\
\text { Integration } \\
\text { (CMMI) }\end{array}$ & $\begin{array}{l}\text { Humphrey } \\
\text { (1988) }\end{array}$ & $\begin{array}{l}\text { Eliminates the need to use } \\
\text { multiple models for software } \\
\text { development by integrating } \\
\text { various CMM models. }\end{array}$ & $\begin{array}{l}\text { 1-initial; 2-managed; 3- } \\
\text { defined; } \\
\text { 4-quantitatively } \\
\text { managed; 5-optimized }\end{array}$ & $\begin{array}{l}\text { Airline, automotive, } \\
\text { banking, education, } \\
\text { engineering, health } \\
\text { care, IT, } \\
\text { telecommunications }\end{array}$ \\
\hline $\begin{array}{l}\text { Berkeley Project } \\
\text { Management } \\
\text { Process Maturity } \\
\text { Model (PM2) }\end{array}$ & $\begin{array}{l}\text { lbbs and } \\
\text { Kwak } \\
(2000)\end{array}$ & $\begin{array}{l}\text { Integrates previous practices, } \\
\text { processes, and maturity } \\
\text { models to improve project } \\
\text { management effectiveness } \\
\text { and allow benchmarking. }\end{array}$ & $\begin{array}{l}\text { 1-basic project } \\
\text { management } \\
\text { processes; 2-individual } \\
\text { project planning; 3- } \\
\text { systematic project } \\
\text { planning and control; } \\
\text { 4-integrated multi- } \\
\text { project planning and } \\
\text { control; 5-continuous } \\
\text { project management } \\
\text { process improvement }\end{array}$ & $\begin{array}{l}\text { Engineering/construc } \\
\text { tion, IT, } \\
\text { telecommunications, } \\
\text { manufacturing }\end{array}$ \\
\hline $\begin{array}{l}\text { Organizational } \\
\text { Project } \\
\text { Management } \\
\text { Maturity Model } \\
\text { (OPM3) }\end{array}$ & PMI (1998) & $\begin{array}{l}\text { Helps organizations } \\
\text { understand project, program, } \\
\text { and portfolio management and } \\
\text { measuring maturity by a wide- } \\
\text { ranging set of best practices. }\end{array}$ & $\begin{array}{l}\text { 1-standardization; 2- } \\
\text { measurement; } \\
\text { 3-control; 4-continuous } \\
\text { improvement }\end{array}$ & $\begin{array}{l}\text { construction, } \\
\text { education, } \\
\text { engineering, gas and } \\
\text { energy, health care, } \\
\text { IT }\end{array}$ \\
\hline $\begin{array}{l}\text { Kerzner Project } \\
\text { Management } \\
\text { Maturity Model } \\
\text { (KPMMM) }\end{array}$ & $\begin{array}{l}\text { Kerzner } \\
(2002)\end{array}$ & $\begin{array}{l}\text { Presents methods to assess } \\
\text { and verify each level of project } \\
\text { management maturity. } \\
\text { Extension of the CMMI model. }\end{array}$ & $\begin{array}{l}\text { 1-common language; } 2- \\
\text { common processes; 3- } \\
\text { singular methodology, } \\
\text { 4-benchmarking; 5- } \\
\text { continuous } \\
\text { development }\end{array}$ & $\begin{array}{l}\text { Education, health } \\
\text { care }\end{array}$ \\
\hline $\begin{array}{l}\text { Project } \\
\text { Management } \\
\text { Maturity Model } \\
\text { (PMMM) }\end{array}$ & $\begin{array}{l}\text { Crawford } \\
(2006)\end{array}$ & $\begin{array}{l}\text { Allows organizations to } \\
\text { systematically and efficiently } \\
\text { develop and measure their } \\
\text { project management } \\
\text { capabilities. }\end{array}$ & $\begin{array}{l}\text { 1-initial process; } 2 \text { - } \\
\text { structured process; 3- } \\
\text { organizational } \\
\text { standards; } \\
\text { 4-managed process; } 5 \text { - } \\
\text { optimized process }\end{array}$ & $\begin{array}{l}\text { Airline, construction, } \\
\text { education, IT }\end{array}$ \\
\hline $\begin{array}{l}\text { Project } \\
\text { Management } \\
\text { Maturity Model } \\
\text { (ProMMM) }\end{array}$ & $\begin{array}{l}\text { Hillson } \\
(2001)\end{array}$ & $\begin{array}{l}\text { Allows diagnosis of the current } \\
\text { maturity level and need for } \\
\text { improvement; provides a } \\
\text { foundation for progress } \\
\text { evaluation. Based on CMM, } \\
\text { EFQM Excellence Model, and } \\
\text { Risk Maturity Model. }\end{array}$ & $\begin{array}{l}\text { 1-naïve; 2-novice; 3- } \\
\text { normalised; } \\
\text { 4-natural }\end{array}$ & - \\
\hline $\begin{array}{l}\text { Portfolio, } \\
\text { Programme, and } \\
\text { Project } \\
\text { Management } \\
\text { Maturity Model } \\
\text { (P3M3) }\end{array}$ & OGC (2006) & $\begin{array}{l}\text { Provides three maturity } \\
\text { models that can be used } \\
\text { separately to focus on specific } \\
\text { areas of the organization and } \\
\text { to help assess the relationship } \\
\text { between portfolios, programs, } \\
\text { and projects. }\end{array}$ & $\begin{array}{l}\text { 1-awareness; } 2 \text { - } \\
\text { repeatable; 3-defined; } \\
\text { 4-managed; 5- } \\
\text { optimized }\end{array}$ & $\begin{array}{l}\text { Public sector, } \\
\text { transportation }\end{array}$ \\
\hline
\end{tabular}

Source: Own elaboration 
First published by Kwak and Ibbs in 1997, the Berkeley Project Management Process Maturity Model (PM2) integrates previous practices, processes, and maturity models with the intent to improve project management effectiveness and allow benchmarking. Like the CMMI, it defines five-albeit different-maturity levels and has been applied in the engineering and construction, IT, telecommunications, and manufacturing industries.

Introduced by the Project Management Institute (PMI) in 2003, the Organizational Project Management Maturity Model (OPM3) was designed to help organizations understand project, program, and portfolio management and allow measuring four levels of maturity by benchmarking against a wide range of best practices. It has been applied, for example, in the construction, education, engineering, gas and energy, health care, and IT industries.

First published by Harold Kerzner in 2002, the Kerzner Project Management Maturity Model (KPMMM) is an extension of the CMMI and presents methods to assess and verify each of five levels of project management maturity. It has been applied in education and health care.

The Project Management Maturity Model (ProMMM) is based on the CMMI, the EFQM Excellence Model, and the Risk Maturity Model and was intended to allow easy diagnosis of an organization's current maturity level and need for improvement, thus providing a foundation for progress evaluation (Hillson, 2001). Although not widely applied at industry level, the model was deemed of relevance by the polled experts because of its simplified evaluation of four maturity levels by evaluating four attributes:culture, process, experience, and application, in a rubric style.

Sharing a name with Hillson's earlier model, PM Solutions' Project Management Maturity Model (PMMM) was first published in 2002 and was developed to allow organizations to systematically and efficiently develop and measure their project management capabilities based on five levels of maturity (Crawford, 2015). It has been applied in the airline, construction, education, and IT industries.

Finally, the Portfolio, Programme, and Project Management Maturity Model (P3M3) is an integrative framework aligned with, for example, the PMI's Project Management Body of Knowledge (PMBOK) and various UK government models. It was first introduced in 2006 by the UK's Office of Government Commerce, although in 2014 ownership was transferred to Axelos, a joint venture between the UK Government and consulting company Capita. The model provides three maturity models - for portfolios, programs, and projects - with five maturity levels each that can be used separately to focus on specific areas of the organization (OGC, 2010). It has been predominantly applied in the public sector and in the transportation industry.

Following the logic of these organizational project management maturity models, it makes sense that a national project management maturity model should also be level-based. While language and number of levels differ between the various models in Table 1, the 
models all follow the same logic, from nascent to mature project management. For national project management maturity, therefore, the following four levels are proposed: nascent, developing, adolescent, and mature.

Nascent maturity implies that there may be some isolated attempts by a few (mainly large) organizations to use project management best practices, but this is neither routine nor systematic, with little support by the government and project management associations. Developing maturity means that project management best practices are only infrequently used by a minority of organizations, without systematic support from the government or professional associations. Adolescent maturity is given if project management best practices are routinely - although not always consistently-used by the majority of organizations, with systematic support by professional associations and some support by the government. Finally, a country is mature regarding national project management maturity if project management is routinely and consistently used by the vast majority of organizations, with systematic support by the government and professional associations.

Table 2 summarizes this.

Table 2 | Definition of NPMM Maturity Levels

\begin{tabular}{|l|l|l|l|}
\hline \multicolumn{4}{|c|}{ National Project Management Maturity } \\
\hline \multicolumn{1}{|c|}{ Level 1: Nascent } & \multicolumn{1}{|c|}{ Level 2: Developing } & \multicolumn{1}{c|}{ Level 3: Adolescent } & \multicolumn{1}{c|}{ Level 4: Mature } \\
\hline $\begin{array}{l}\text { There are some } \\
\text { isolated attempts by } \\
\text { some (mainly large) } \\
\text { organizations to use } \\
\text { project management } \\
\text { best practices, but } \\
\text { this is neither routine } \\
\text { nor systematic, with } \\
\text { little support by the } \\
\text { government and } \\
\text { professional } \\
\text { associations. }\end{array}$ & $\begin{array}{l}\text { Project management } \\
\text { infrequently used by a } \\
\text { minority of } \\
\text { organizations, without } \\
\text { systematic support } \\
\text { from the government or } \\
\text { professional } \\
\text { associations. }\end{array}$ & $\begin{array}{l}\text { Project management } \\
\text { best practices are } \\
\text { routinely but often } \\
\text { inconsistently used by } \\
\text { the majority of } \\
\text { organizations, with } \\
\text { systematic support by } \\
\text { professional } \\
\text { associations and some } \\
\text { support by the } \\
\text { government. }\end{array}$ & $\begin{array}{l}\text { Project management } \\
\text { is routinely and } \\
\text { the vast majority of } \\
\text { organizations, with } \\
\text { systematic support by } \\
\text { the government and } \\
\text { professional } \\
\text { associations. }\end{array}$ \\
\hline
\end{tabular}

Source: Own elaboration

With these levels defined, the next question is how to gauge the maturity level of a country. Importantly, all of the organizational project management maturity models except the ProMMM define a varying number of so-called knowledge areas, i.e. specific areas that the organization must know about in order to gauge maturity. The PMMM, KPMMM, and OPM3 each define ten, the PM2 nine, and the CMMI eight such knowledge areas. The P3M3 does not specifically refer to knowledge areas but instead defines seven perspectives, although contextually these conform to the knowledge areas of the other models. When put together, a list of 34 knowledge areas and perspectives results. By comparing these and eliminating those that refer to the same concept, 18 distinct knowledge areas emerge. In alphabetical order, these are: benefits management, 
communications management, cost and finance management, governance management, integration management, monitoring and controlling, performance management, planning management, product and process management, quality management, resource management, risk management, scope management, stakeholder management, strategic management, supplier and procurement management, teaming and HR management, and time management. Table 3 provides an overview of these 18 knowledge areas and whether they are included or not in each of the seven models.

However, this comparatively large number of knowledge areas may lead to an unwieldy, inflexible, and unnecessarily complex assessment process. With regard to national project management maturity, therefore, in line with Hillson (2001) these 18 core knowledge areas were condensed into eight proposed national project management maturity (NPMM) perspectives: project governance and controlling (combining governance management and monitoring and controlling); project planning and organization (consisting of integration, scope, product and process, strategic, teaming and HR, and planning management), project execution (merging time, performance, and benefits management), project communications management, project resource management (consisting of cost and finance, supplier and procurement, and resource management), project quality management, project risk management, and project stakeholder management. Table 3 summarizes these deliberations and provides details on how these NPMM perspectives were derived.

In contrast to the other models discussed, Hillson's (2001) Project Management Maturity Model (ProMMM) does not define specific knowledge areas but lists four 'attributes'culture, process, experience, and application - that are used to describe the organization's project management maturity using a kind of rubric. Regarding national project management maturity, this seems a sensible approach because, due to the myriad differences between countries, keeping the resulting model to a fairly abstract level should make it more generally applicable. Hillson's 'attributes' can be considered drivers of project management maturity because governments and project management associations may actively support them. When applying this logic and adapting Hillson's approach to the national level, this leads to four maturity drivers: national project management culture, national project management process saturation, national project management experience sharing, and national project management application support. 
Table 3 | Derivation of NPMM Perspectives

\begin{tabular}{|c|c|c|c|c|c|c|c|c|c|}
\hline & & Matu & rity Mc & odels & & & & & \\
\hline $\begin{array}{l}\text { Kn } \\
\text { Are }\end{array}$ & $\begin{array}{l}\text { Nledge } \\
\text { s }\end{array}$ & CMMI & PM2 & OPM3 & KPMMM & PMMM & ProMMM & P3M3 & $\begin{array}{l}\text { NPMM } \\
\text { Perspectives }\end{array}$ \\
\hline 1 & $\begin{array}{l}\text { Governance } \\
\text { management }\end{array}$ & & & $x$ & & & & $x$ & Project \\
\hline 2 & $\begin{array}{l}\text { Monitoring and } \\
\text { controlling }\end{array}$ & $x$ & & & & & & $x$ & $\begin{array}{l}\text { governance and } \\
\text { controlling }\end{array}$ \\
\hline 3 & $\begin{array}{l}\text { Integration } \\
\text { management }\end{array}$ & & $x$ & & $x$ & $x$ & & & \\
\hline 4 & $\begin{array}{l}\text { Scope } \\
\text { management }\end{array}$ & & $x$ & & $x$ & $x$ & & & \\
\hline 5 & $\begin{array}{l}\text { Product and } \\
\text { process } \\
\text { management }\end{array}$ & $x$ & & & & & & & Project planning \\
\hline 6 & $\begin{array}{l}\text { Strategic } \\
\text { management }\end{array}$ & & & $x$ & & & & & $\begin{array}{l}\text { and } \\
\text { organization }\end{array}$ \\
\hline 7 & $\begin{array}{l}\text { Teaming and } \\
\text { HR } \\
\text { management }\end{array}$ & $x$ & $x$ & & $x$ & $x$ & & & \\
\hline 8 & $\begin{array}{l}\text { Planning } \\
\text { management }\end{array}$ & $x$ & & & & & & & \\
\hline 9 & $\begin{array}{l}\text { Time } \\
\text { management }\end{array}$ & & $x$ & & $x$ & $x$ & & & \\
\hline 10 & $\begin{array}{l}\text { Performance } \\
\text { management }\end{array}$ & & & $x$ & & & & & Project execution \\
\hline 11 & $\begin{array}{l}\text { Benefits } \\
\text { management }\end{array}$ & & & & & & & $x$ & \\
\hline 13 & $\begin{array}{l}\text { Communication } \\
\text { s management }\end{array}$ & & $x$ & $x$ & $x$ & $x$ & & & $\begin{array}{l}\text { Project } \\
\text { communications } \\
\text { management }\end{array}$ \\
\hline 12 & $\begin{array}{l}\text { Cost and } \\
\text { finance } \\
\text { management }\end{array}$ & & $x$ & & $x$ & $x$ & & $x$ & \\
\hline 14 & $\begin{array}{l}\text { Supplier/procure } \\
\text { ment } \\
\text { management }\end{array}$ & $x$ & $x$ & & $x$ & $x$ & & & $\begin{array}{l}\text { Project resource } \\
\text { management }\end{array}$ \\
\hline 15 & $\begin{array}{l}\text { Resource } \\
\text { management }\end{array}$ & & & & & & & $x$ & \\
\hline 16 & $\begin{array}{l}\text { Quality } \\
\text { management }\end{array}$ & & $x$ & & $x$ & $x$ & & & $\begin{array}{l}\text { Project quality } \\
\text { management }\end{array}$ \\
\hline 17 & $\begin{array}{l}\text { Risk } \\
\text { management }\end{array}$ & $x$ & $x$ & $x$ & $x$ & $x$ & & $x$ & $\begin{array}{l}\text { Project risk } \\
\text { management }\end{array}$ \\
\hline 18 & $\begin{array}{l}\text { Stakeholder } \\
\text { management }\end{array}$ & & & & $x$ & $x$ & & $x$ & $\begin{array}{l}\text { Project stakeholder } \\
\text { management }\end{array}$ \\
\hline
\end{tabular}

Source: Own elaboration

National project management culture refers to the existence and characteristics of a system and mindset, at the national level, that fosters project management best practice. The more effective and efficient such a system and the more natural such a mindset, the higher national project management maturity is.

National project management process saturation indicates how widely used standardized project management processes are. The more this becomes second nature in as many organizations as possible, the higher maturity is. 
National project management experience sharing refers to the availability of information-and the efficiency with which it can be accessed-about project management best practices and lessons learned. Regulations that enforce the sharing of project charters and reports or the existence of experience-sharing platforms contribute to higher maturity.

Finally, national project management application support refers to initiatives and systems of government entities and professional associations that support organizations when managing their projects. Examples are freely available project management methodologies, such as the Swiss government's HERMES or the European Union's OpenPM2. Project risk mitigation mechanisms, such as export risk guarantees for large construction projects, can also be considered part of this.

Figure 1 summarizes the final national project management maturity model, or NPM3.

Figure 1 | National Project Management Maturity Model (NPM3)

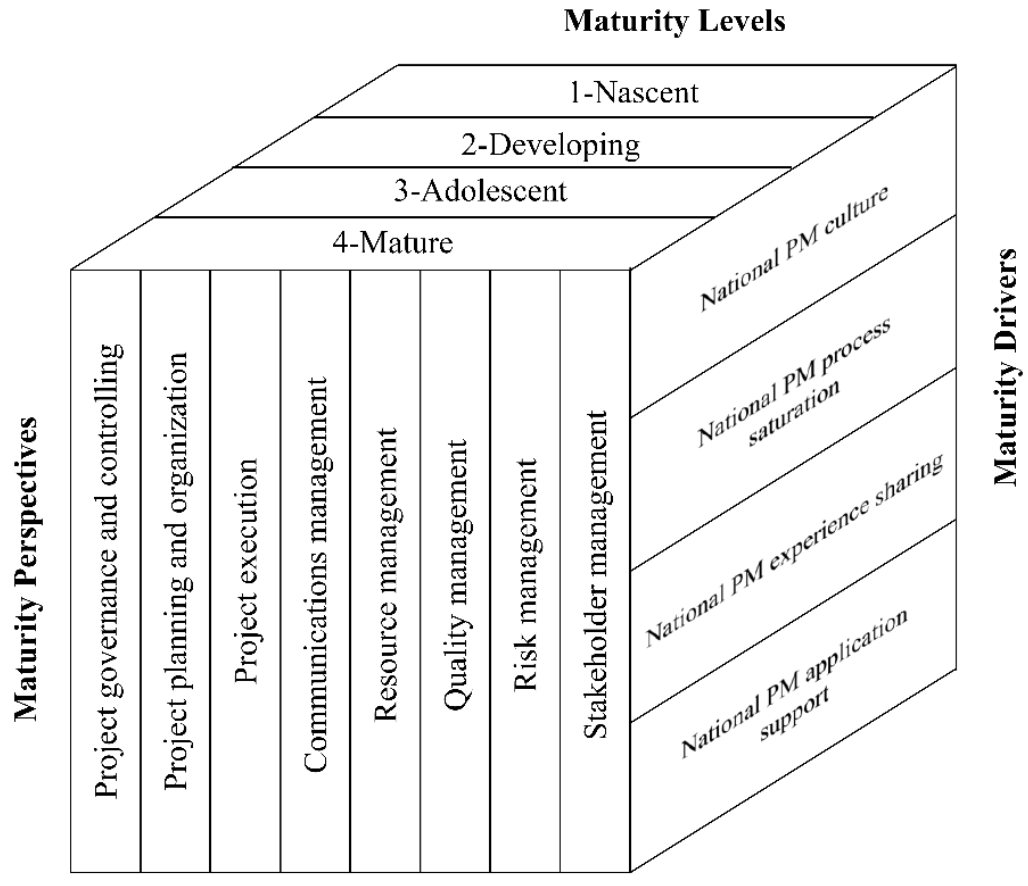

The NPM3 closely follows the conceptual approach of relevant organizational project management maturity models. It necessarily diverges regarding key performance indicators (KPI), however, to compare the project management maturity of two countries, a much higher level of aggregation and some specifically country-level indicators is required. 
Regarding project governance and controlling, the stringency with which project governance is adhered to at a national scale-particularly in the case of large private projects and public projects of national significance-indicates how mature the country's NPMM is: the higher the number of projects that conform to a defined standard regarding project oversight and controlling, the more mature. The same is true for planning and execution conformity, i.e. the number of organizations that adhere to a defined standard regarding project planning and execution. This includes both the processes employed and the best practices used as a benchmark. The specific standard used should not matter as much as the fact that each project is planned and executed according to one.

With regard to the management of project communications, transparency is highly relevant at the national level. Particularly in the case of projects of national significance, pertinent information often only surfaces once the press starts digging in case of scandal or failure. This transparency principle should apply to all—not just large public — projects, however, as this contributes to a positive national project management culture.

When it comes to project resource management, which includes project-related factors such as cost or finance and supplier/procurement management, two aspects are particularly indicative of national project management maturity: consultant support and overall project success rate. Consultant support relates to the perceived necessity to include external consultants in a project. A high proportion of the overall budget spent on consultants indicates that an organization's project management is not mature enough to handle these projects alone. By aggregating and averaging this figure across all pertinent organizations, the same factor can be calculated at the national level. A second important number is the overall ratio of successful to unsuccessful projects. At its most basic, success can be defined as reaching the defined goals on time and on budget. A higher the aggregate number correlates to the higher national project management maturity.

With regard to project quality and risk management, stringency of adherence and reporting are two key aspects. At its most basic, stringency can be defined as the number of projects that have regular quality and risk assessments. Ideally, this follows a standard methodology, but the main thing is that these assessments occur on a regular basis. Reports - final or, particularly in the case of large, complex projects, also intermediateabout project quality assessments and risk reports should be made publicly available. These may be standalone; however, this kind of information is often included in a project charter and/or final report.

Similar to quality management, risk management must be stringently applied and transparently and systematically reported. The more that projects have regular project risk assessments and the more risk-related project information is available, the higher maturity.

Finally, information about who a project's stakeholders are and what their influence onand their contributions to-said project are should be known. This reduces opportunities 
for corruption and prevents the kind of scandal that regularly occurs when journalists digs out undisclosed stakeholders and their conflicts of interest, particularly in troubled, nationally significant projects. Table 4 summarizes these points.

The maturity perspectives described above provide a good picture of the state of project management at the national level. How fast national project management maturity improves is largely determined by the maturity drivers, however, and these should therefore also be assessed. Like in the case of the afore-mentioned maturity perspectives, this can be done using key performance indicators.

Table 4 | NPMM Perspectives and Key Performance Indicators

\begin{tabular}{|c|c|c|c|c|c|c|}
\hline \multirow{2}{*}{\multicolumn{2}{|c|}{$\begin{array}{c}\text { NPMM } \\
\text { Perspectives }\end{array}$}} & \multirow{3}{*}{\begin{tabular}{l}
\multicolumn{1}{c}{ Key } \\
$\begin{array}{c}\text { Performance } \\
\text { Indicators } \\
\text { KPI } \\
\text { (examples) }\end{array}$ \\
$\begin{array}{l}\text { Stringency of } \\
\text { project } \\
\text { governance }\end{array}$
\end{tabular}} & \multirow{3}{*}{ 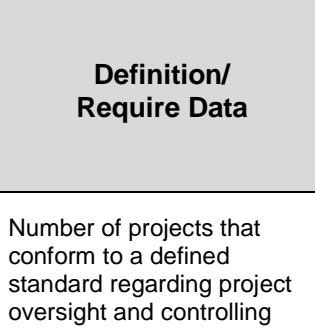 } & \multicolumn{3}{|c|}{ Maturity Contribution } \\
\hline & & & & \multirow{2}{*}{$\begin{array}{r}\text { High } \\
\text { (3) } \\
\text { Majority }\end{array}$} & \multirow{2}{*}{$\begin{array}{l}\begin{array}{c}\text { Medium } \\
(2)\end{array} \\
\text { Some }\end{array}$} & \multirow{2}{*}{$\begin{array}{l}\text { Low } \\
\text { (1) }\end{array}$} \\
\hline 1 & $\begin{array}{l}\text { Project } \\
\text { governance } \\
\text { and } \\
\text { controlling }\end{array}$ & & & & & \\
\hline 2 & $\begin{array}{l}\text { Project } \\
\text { planning and } \\
\text { organization }\end{array}$ & $\begin{array}{l}\text { Planning } \\
\text { conformity }\end{array}$ & $\begin{array}{l}\text { Number of projects that are } \\
\text { planned according to a } \\
\text { standard methodology }\end{array}$ & Majority & Some & $\begin{array}{l}\text { Hardly any } \\
\text { or none }\end{array}$ \\
\hline 3 & $\begin{array}{l}\text { Project } \\
\text { execution }\end{array}$ & $\begin{array}{l}\text { Execution } \\
\text { conformity }\end{array}$ & $\begin{array}{l}\text { Number of projects that are } \\
\text { executed according to a } \\
\text { standard methodology }\end{array}$ & Majority & Some & $\begin{array}{l}\text { Hardly any } \\
\text { or none }\end{array}$ \\
\hline 4 & $\begin{array}{l}\text { Project } \\
\text { communicati } \\
\text { ons } \\
\text { management }\end{array}$ & $\begin{array}{l}\text { Project } \\
\text { transparency }\end{array}$ & $\begin{array}{l}\text { Availability of information } \\
\text { about significant projects, } \\
\text { including project charters, } \\
\text { progress reports, and final } \\
\text { reports with lessons learned }\end{array}$ & $\begin{array}{l}\text { Widely } \\
\text { available }\end{array}$ & $\begin{array}{l}\text { Some } \\
\text { available }\end{array}$ & $\begin{array}{l}\text { Hardly any } \\
\text { or none } \\
\text { available }\end{array}$ \\
\hline \multirow[t]{2}{*}{5} & \multirow[t]{2}{*}{$\begin{array}{l}\text { Project } \\
\text { resource } \\
\text { management }\end{array}$} & $\begin{array}{l}\text { Consultant } \\
\text { support }\end{array}$ & $\begin{array}{l}\text { Percentage of overall } \\
\text { project budgets spent on } \\
\text { consultants }\end{array}$ & Low & Medium & High \\
\hline & & $\begin{array}{l}\text { Project success } \\
\text { rate }\end{array}$ & $\begin{array}{l}\text { Number of projects that } \\
\text { reach their goals on time } \\
\text { and on budget }\end{array}$ & Majority & Some & $\begin{array}{l}\text { Hardly any } \\
\text { or none }\end{array}$ \\
\hline \multirow[t]{2}{*}{6} & \multirow[t]{2}{*}{$\begin{array}{l}\text { Project } \\
\text { quality } \\
\text { management }\end{array}$} & $\begin{array}{l}\text { Stringency of } \\
\text { project quality } \\
\text { management }\end{array}$ & $\begin{array}{l}\text { Number of projects that } \\
\text { have regular project quality } \\
\text { assessments }\end{array}$ & Majority & Some & $\begin{array}{l}\text { Hardly any } \\
\text { or none }\end{array}$ \\
\hline & & $\begin{array}{l}\text { Project quality } \\
\text { management } \\
\text { reporting }\end{array}$ & $\begin{array}{l}\text { Public availability of project } \\
\text { quality reports }\end{array}$ & $\begin{array}{l}\text { Widely } \\
\text { available }\end{array}$ & $\begin{array}{l}\text { Some } \\
\text { available }\end{array}$ & $\begin{array}{l}\text { Hardly any } \\
\text { or none } \\
\text { available }\end{array}$ \\
\hline
\end{tabular}




\begin{tabular}{|c|l|l|l|l|l|l|}
\hline 7 & $\begin{array}{l}\text { Project risk } \\
\text { management }\end{array}$ & $\begin{array}{l}\text { Stringency of } \\
\text { project risk } \\
\text { management }\end{array}$ & $\begin{array}{l}\text { Number of projects that } \\
\text { have regular project risk } \\
\text { assessments }\end{array}$ & Majority & Some & $\begin{array}{l}\text { Hardly any } \\
\text { or none }\end{array}$ \\
\cline { 2 - 6 } & $\begin{array}{l}\text { Project risk } \\
\text { management } \\
\text { reporting }\end{array}$ & $\begin{array}{l}\text { Public availability of project } \\
\text { risk reports }\end{array}$ & $\begin{array}{l}\text { Widely } \\
\text { available }\end{array}$ & $\begin{array}{l}\text { Some } \\
\text { available }\end{array}$ & $\begin{array}{l}\text { Hardly any } \\
\text { or none } \\
\text { available }\end{array}$ \\
\hline 8 & $\begin{array}{l}\text { Project } \\
\text { stakeholder } \\
\text { management }\end{array}$ & $\begin{array}{l}\text { Stakeholder } \\
\text { transparency }\end{array}$ & $\begin{array}{l}\text { Availability of information } \\
\text { about project stakeholders } \\
\text { and their influence and } \\
\text { contributions }\end{array}$ & $\begin{array}{l}\text { Widely } \\
\text { available }\end{array}$ & $\begin{array}{l}\text { Some } \\
\text { available }\end{array}$ & $\begin{array}{l}\text { Hardly any } \\
\text { or none } \\
\text { available }\end{array}$ \\
\hline
\end{tabular}

Source: Own elaboration

To foster a national project management culture conducive to project management best practice, four aspects are particularly important: projectification, the professional status of project managers, project-related career opportunities, and a general project management mindset.

Projectification in this context means the percentage of all activities carried out as projects.

This is seen as positive because projects are considered to be a suitable organizational form to react flexibly to internal and external changes, generate innovations, and solve complex or novel problems (Wald et al., 2015). The higher this number, therefore, the more this drives maturity. Likewise, the higher the professional status of project managers, the larger this aspect contributes to maturity. Both points could be quantitatively or qualitatively defined. If the data can be obtained, a quantitative assessment will foster better comparability between countries. In order to identify improvement potential, however, having experts make a comparative assessment based on Tables 4 and 5 will already be valuable, too.

Finally, a project management mindset-running activities as projects whenever possible - also contributes to maturity. This is a hard to grasp - and even harder to measure-concept, however. One simple and normally fairly easily available proxy could be to use the number of registered members of large international project associationssuch as PMI, IPMA, and IPMA-associated certification bodies like APM in the United Kingdom - and put that number in perspective to the overall workforce. For example, in 2017 Switzerland had a workforce of 5.01 million. In the same year, PMI's Swiss chapter had 1,400 members, while IPMA's local member entity, the Swiss Project Management Association, came to about 900 members. The fraction of project management association members in relation to the total workforce was thus around 0.4 per-mille. In contrast, in the UK, PMI membership was about 3,500 and APM membership around 23,000 in the same year. Compared to a workforce of 31.11 million, this brings the same fraction to roughly 0.8 per-mille, or about twice that of Switzerland. Although these are very small numbers, it seems clear that with regard to this particular factor, the UK is considerably more mature. 
A more qualified statement could be made, however, by calculating and comparing this figure for all countries and, for example, determining the quartile to which each belongs.

National project management process saturation refers to how widely used standardized project management processes are. Ideally, this would encompass the use of standardized methodologies like PRINCE2, IPM, or PRiSM. As there are a large number of such methodologies, however, and reliably determining their stringent application would be almost impossible, a more manageable proxy is needed. One possibility is the number of specialized university programs with a project management focus. This is normally indicated by a program carrying "project management" in the official program name and/or degree awarded. As a university may also have project management expertise not reflected in a program's title, however, organizational units specifically dedicated to project management should be included.

The level of systematic experience sharing about project management best practices and lessons learned in a country can be facilitated by the government and/or professional associations. The more systematic and widespread, the stronger the contribution to maturity. The availability of data about project management's best practices and lessons learned on one hand and the average remuneration of project managers on the other seem particularly relevant.

Finally, several factors influence project management application support at the national level. Specifically, the degree of research funding for project management-related topics, the existence of government or private support initiatives and systems to help organizations identify and mitigate project risks, and the availability of free project management methodologies supported by the government or large professional associations, such as the Swiss government's HERMES or the European Union's OpenPM2, all increase maturity. Table 5 lists these NPMM maturity drivers, along with associated key performance indicators and their maturity contribution.

Table 5 | NPMM Maturity Drivers and Key Performance Indicators

\begin{tabular}{|c|c|c|c|c|c|c|}
\hline & \multirow[b]{2}{*}{$\begin{array}{l}\text { NPMM } \\
\text { Maturity } \\
\text { Drivers }\end{array}$} & \multirow{2}{*}{$\begin{array}{c}\text { Key } \\
\text { Performance } \\
\text { Indicators } \\
\text { KPI } \\
\text { (examples) }\end{array}$} & \multirow[b]{2}{*}{$\begin{array}{c}\text { Definition/ } \\
\text { Require Data }\end{array}$} & \multicolumn{3}{|c|}{ Maturity Contribution } \\
\hline & & & & $\begin{array}{l}\text { High } \\
\text { (3) }\end{array}$ & $\begin{array}{l}\text { Medium } \\
\text { (2) }\end{array}$ & $\begin{array}{l}\text { Low } \\
\text { (1) }\end{array}$ \\
\hline \multirow[t]{4}{*}{1} & \multirow{4}{*}{$\begin{array}{l}\text { National } \\
\text { project } \\
\text { management } \\
\text { culture }\end{array}$} & Projectification & $\begin{array}{l}\text { Percentage of all activities } \\
\text { carried out as projects }\end{array}$ & Majority & Some & $\begin{array}{l}\text { Hardly any } \\
\text { or none }\end{array}$ \\
\hline & & $\begin{array}{l}\text { Project manager } \\
\text { status }\end{array}$ & $\begin{array}{l}\text { Professional status of } \\
\text { project managers }\end{array}$ & High regard & $\begin{array}{l}\text { No special } \\
\text { recognition }\end{array}$ & $\begin{array}{l}\text { Low regard } \\
\text { or ignored }\end{array}$ \\
\hline & & $\begin{array}{l}\text { Project-based } \\
\text { career } \\
\text { opportunities }\end{array}$ & $\begin{array}{l}\text { Number of certified project } \\
\text { managers in relation to } \\
\text { other countries }\end{array}$ & Top quartile & $\begin{array}{l}\text { Second and } \\
\text { third quartile }\end{array}$ & $\begin{array}{l}\text { Bottom } \\
\text { quartile }\end{array}$ \\
\hline & & $\begin{array}{l}\text { Project } \\
\text { management }\end{array}$ & $\begin{array}{l}\text { Number of project } \\
\text { management association }\end{array}$ & Top quartile & $\begin{array}{l}\text { Second and } \\
\text { third quartile }\end{array}$ & $\begin{array}{l}\text { Bottom } \\
\text { quartile }\end{array}$ \\
\hline
\end{tabular}




\begin{tabular}{|c|c|c|c|c|c|c|}
\hline & & mindset & $\begin{array}{l}\text { members as a percentage } \\
\text { of the overall workforce }\end{array}$ & & & \\
\hline \multirow[t]{2}{*}{2} & \multirow{2}{*}{$\begin{array}{l}\text { National } \\
\text { project } \\
\text { management } \\
\text { process } \\
\text { saturation }\end{array}$} & $\begin{array}{l}\text { Tertiary project } \\
\text { management } \\
\text { programs }\end{array}$ & $\begin{array}{l}\text { Percentage of universities } \\
\text { with dedicated project } \\
\text { management programs }\end{array}$ & Majority & Some & $\begin{array}{l}\text { Hardly any } \\
\text { or none }\end{array}$ \\
\hline & & $\begin{array}{l}\text { Tertiary project } \\
\text { management } \\
\text { units }\end{array}$ & $\begin{array}{l}\text { Percentage of universities } \\
\text { with dedicated project } \\
\text { management units (e.g. } \\
\text { centers) }\end{array}$ & Majority & Some & $\begin{array}{l}\text { Hardly any } \\
\text { or none }\end{array}$ \\
\hline \multirow[t]{2}{*}{3} & \multirow[t]{2}{*}{$\begin{array}{l}\text { National } \\
\text { project } \\
\text { management } \\
\text { experience } \\
\text { sharing. }\end{array}$} & $\begin{array}{l}\text { Project } \\
\text { management } \\
\text { data access }\end{array}$ & $\begin{array}{l}\text { General availability of data } \\
\text { about project management } \\
\text { best practices and lessons } \\
\text { learned }\end{array}$ & Good & Medium & Bad \\
\hline & & $\begin{array}{l}\text { Project manager } \\
\text { remuneration } \\
\text { data }\end{array}$ & $\begin{array}{l}\text { Availability of data } \\
\text { specifically relating to the } \\
\text { remuneration of project } \\
\text { managers }\end{array}$ & Good & Medium & Bad \\
\hline \multirow[t]{3}{*}{4} & \multirow[t]{3}{*}{$\begin{array}{l}\text { National } \\
\text { project } \\
\text { management } \\
\text { application } \\
\text { support. }\end{array}$} & $\begin{array}{l}\text { Degree of } \\
\text { national project } \\
\text { management } \\
\text { research funding }\end{array}$ & $\begin{array}{l}\text { Public spending in relation } \\
\text { to other countries }\end{array}$ & Top quartile & $\begin{array}{l}\text { Second and } \\
\text { third quartile }\end{array}$ & $\begin{array}{l}\text { Bottom } \\
\text { quartile }\end{array}$ \\
\hline & & $\begin{array}{l}\text { Degree of risk } \\
\text { protection }\end{array}$ & $\begin{array}{l}\text { Availability of government or } \\
\text { private support initiatives } \\
\text { and systems to help } \\
\text { organizations identify and } \\
\text { mitigate project risks }\end{array}$ & $\begin{array}{l}\text { Widely } \\
\text { available }\end{array}$ & Some & $\begin{array}{l}\text { Hardly any } \\
\text { or none }\end{array}$ \\
\hline & & $\begin{array}{l}\text { Sponsored } \\
\text { project } \\
\text { management } \\
\text { methodologies }\end{array}$ & $\begin{array}{l}\text { Availability of freely } \\
\text { available project } \\
\text { management methodologies } \\
\text { supported by the } \\
\text { government or large } \\
\text { professional associations }\end{array}$ & $\begin{array}{l}\text { Two or } \\
\text { more } \\
\text { available }\end{array}$ & $\begin{array}{l}\text { One } \\
\text { available }\end{array}$ & $\begin{array}{l}\text { None } \\
\text { available }\end{array}$ \\
\hline
\end{tabular}

Source: Own elaboration

Now that both project management maturity perspectives and drivers have been identified and operationally defined, a country's national project management maturity can be assessed. Using the simple rubrics in Tables 4 and 5, the level of maturity contribution (high, medium, or low) can be determined for each maturity perspective and maturity driver. After completion, an overall picture will emerge that roughly indicates national project management maturity. To interpret it, a simple linear scoring system may be helpful. Specifically, if high contributions are assigned a value of two, medium contributions a value of one, and low contributions a value of zero, and assuming that high maturity will, at a minimum, consist of eleven high and ten medium contributions and medium maturity of at least eleven medium and ten low contributions, the following overall assessment scale emerges:

- 32-42 points: High national project management maturity

- 11-31 points: Medium national project management maturity

- 0-10 points: Low national project management maturity 
Clearly, the above scale is not yet evidence-based. Empirically determining appropriate numeric levels will need further research.

\section{Conclusion}

Like its organizational-level counterparts, a systematic model of national project management maturity can help to gain a better understanding of a country's project management-related strengths and weaknesses. If organizational project management maturity can improve the bottom-line of these organizations, then national project management maturity will likely also have an aggregate economic impact. Of course, collecting the necessary information at the national level can be daunting. That does not mean it should not be attempted, however. The more dynamic markets and technologies become, the more valuable project management skills become. By applying the NPM3 framework developed in this paper, a country's government can actively promote and support, rather than just passively track or even ignore, project management skills in its domestic public and private organizations. The concept of national project management maturity can also contribute to gaining a better understanding of the roles that various actors in a country, such as government entities, professional associations, universities, and so on, play in the successful implementation of projects. Such an understanding, in turn, can be valuable both for supporting the growth of new and the transformation of obsolete industries and sectors. Furthermore, it can help to identify potentials and shortcomings in nationally significant projects. This facilitates the reduction of failure-related financial, political, and/or reputational damage by improving the professionalism with which they are planned and executed. Additionally, this can improve sustainability in the context of such projects, such as in the case of the responsible urban development that accompanied the 2012 Summer Olympics in London, which stands in stark contrast to the derelict ruins left by various large-scale events in other locations. In summary, national project management maturity is an overdue concept with clear practical implications.

This paper should be seen as a first attempt at defining a national project management maturity model. Particularly the various examples of key performance indicators provided for the maturity perspectives and drivers are, by necessity, still quite generic. Additionally, the criteria by which a key performance indicators' maturity contribution is gauged are only very roughly defined. Future research into the area of national project management maturity should therefore aim to empirically validate these key performance indicators in various contexts and further refine the associated operational definitions.

\section{References}

Alami, O. M., Bouksour, O., \& Beidouri, Z. (2015). An Intelligent Project Management Maturity Model For Moroccan Engineering Companies. The Journal for Decision Makers, 40(2), 191-208. 
Backlund, F., Chronéer, D., \& Sundqvist, E. (2014). Project Management Maturity Models-A Critical Review: A Case Study within Swedish Engineering and Construction Organizations. Procedia-Social and Behavioral Sciences, 119, 837846.

Besner, C., \& Hobbs, B. (2013). Contextualized Project Management Practice: A Cluster Analysis Of Practices And Best Practices. Project Management Journal, 44(1), 17 34.

Cooke-Davies, T. J., \& Arzymanow, A. (2003). The Maturity of Project Management in

Different Industries: An Investigation Into Variations Between Project Management Models. International Journal of Project Management, 21(6), 471-478.

Crawford, J. K. (2006). The Project Management Maturity Model. Information Systems Management, 23(4), 50-58.

Crawford, K. J. (2015). Project Management Maturity Model, 3rd ed. Boca Raton, FL: CRC Press.

Bushuyev, S. D., \& Wagner, R. F. (2014). IPMA Delta and IPMA Organizational Competence Baseline (OCB): New Approaches in the Field of Project Management Maturity. International Journal of Managing Projects in Business, 7(2), 302-310.

Foti, Ross. (2002). Ma•tu•ri॰ty (me-tur-e-te) Noun, 21st Century-Synonym: Survival. PM Network, 16 (9), 39-43.

Ghoddousi, P., Amini, Z., \& Hosseini, M. R. (2011). A Survey on the Maturity State of Iranian Grade One Construction Companies Utilizing OPM3 Maturity Model. Technics Technologies Education Management, 6(1), 69-77.

Grant, K. P., \& Pennypacker, J. S. (2006). Project Management Maturity: An Assessment of Project Management Capabilities Among and Between Selected Industries. IEEE Transactions on Engineering Management, 53(1), 59-68.

Hillson, D. (2001). Benchmarking Organizational Project Management Capability. In Proceedings of the 32nd Annual Project Management Institute 2001 Seminars \& Symposium.

Hillson, D. (2003). Assessing Organizational Project Management Capability. Journal of Facilities Management, 2(3), 298-311.

Humphrey, W. S. (1988). Characterizing the Software Process: A Maturity Framework. IEEE Software, 5(2), 73-79.

Ibbs, C. W., \& Kwak, Y. H. (1997). Measuring Project Management's Return on Investment. PM NETwork, 11(11), 36-38.

Ibbs, C. W., \& Kwak, Y. H. (2000). Assessing Project Management Maturity. Project Management Journal, 31(1), 32-43.

Jugdev, K. \& Thomas, J. (2002). Project Management Maturity Models: The Silver Bullets of Competitive Advantage? Project Management Journal, 33(4), 4-14.

Kerzner, H. R. (2002). Strategic Planning For Project Management Using a Project Management Maturity Model. New York: John Wiley \& Sons.

KPMG (2017). Driving Business Performance - Project Management Survey 2017.

Retrieved April 2, 2018 from https://home.kpmg.com/nz/en/home.html. 
Kreiner, C. (2014). Restoring Project Success as Phenomenon. In Lundin, R. A. \& Hällgren, M. (Eds.), Advancing Research on Projects and Temporary Organizations (pp. 19-36). Copenhagen: Copenhagen Business School Press. Lundin, R. A., \& Hällgren, M. (2014). Advancing Research on Projects and Temporary Organizations. Copenhagen: Copenhagen Business School Press.

Mapepeta, B. (2016). Background to the Study of "The Impact of Project Failure on the Socio-Economic Development in Zimbabwe: A Case of Masvingo Province”. PM World Journal, 5(8), 1-21.

Mihic, M. M., Petrovic, D. C., Obradovic, V. L., \& Vuckovic, A. M. (2015). Project Management Maturity Analysis in the Serbian Energy Sector. MDPI Energies, 8(5), 3924-3943.

Milosevic, D. Z. (2003). Project Management Toolbox: Tools and Techniques for the Practicing Project Manager. Hoboken, NJ: John Wiley \& Sons.

Mullaly, M. (2006). Longitudinal Analysis of Project Management Maturity. Project Management Journal, 36(3), 62-73.

Narbaev, T. (2015). An Assessment of Project Management Maturity in Kazakhstan. PM World Journal, 4(11), 1-20.

Ofori, D., \& Deffor, E. W. (2013). Assessing Project Management Maturity in Africa: A Ghanaian Perspective. International Journal of Business Administration, 4(6), 4161.

OGC (2006). Portfolio, Programme and Project Management Maturity Model (P3M3) -

Introduction and Guide to P3M3, Version 2.1. London: Office of Government Commerce.

Pennypacker, J. S., \& Grant, K. P. (2003). Project Management Maturity: An Industry Benchmark. Project Management Journal, 34(1), 4-11.

Pinto, J. K., \& Prescott, J. (1988). Variations in Critical Success Factors over the Stages in the Project Life Cycle. Journal of Management, 14(1), 5-18.

PMI (2003). Organizational Project Management Maturity Model (OPM3)—Knowledge

Foundation. Newtown Square, PA: Project Management Institute.

PMI (2013). Organizational Project Management Maturity Model, 3rd ed. Newtown

Square, PA: Project Management Institute.

PMI (2016). PMI's 8th Global Project Management Survey. Retrieved April 3, 2018 from https://www.pmi.org/-/media/pmi/documents/public/pdf/learning/thoughtleadership/pulse/pulse-of-the-profession-2016.pdf.

Porter, M. (1990). The Competitive Advantage of Nations. New York: Free Press.

Pretorius, S., Steyn, H., \& Jordaan, J. C. (2012). Project Management Maturity and Project Management Success in the Engineering and Construction Industries in Southern Africa. South African Journal of Industrial Engineering, 23(3), 1-12.

Puus, U., \& Mets, T. (2010). Software Development Maturity Evaluation: Six Cases from Estonian SMEs. Baltic Journal of Management, 5(3), 422-443.

Saures, I. (1998). A Real World Look at Achieving Project Management Maturity. In Project Management Institute 29th Annual Symposium. 
Schlichter, J., \& Skulmoski, G. (2000). Organisational Project Management Maturity: New Frontiers. In Proceedings of 15th IPMA World Congress on Project Management.

Shenhar, A. J., Levy, O., \& Dvir, D. (1997). Mapping the Dimensions of Project Success. Project Management Journal, 28(2), 5-13.

Silva, D., Tereso, A., Fernandes, G., \& Pinto, J. A. (2014). OPM3 Portugal Project: Analysis of Preliminary Results. Procedia Technology, 16, 1027-1036.

Simangunsong, E., \& Da Silva, E. (2013). Analyzing Project Management Maturity Level in Indonesia. The South East Asian Journal of Management, 7(1), 72-84.

Skulmoski, G. (2001). Project Maturity and Competence Interface. Cost Engineering, 43(6), 11-18.

Srivannaboon, S. (2009). Achieving Competitive Advantage Through the Use of Project Management under the Plan-Do-Check-Act Concept. Journal of General Management, 34(3), 1-20.

The Standish Group (2018). Chaos Report. Retrieved April 3, 2018 from https://www.standishgroup.com/outline.

Torres, L. C. (2014). A Contingency View on the Effect of Project Management Maturity on Perceived Performance. Doctoral dissertation. Lille: Skema Business School.

Wald, A., Spanuth, T., Schneider, C., Futterer, F., Schnellbächer, B., \& Schoper, Y. (2015). Makroökonomische Vermessung der Projekttätigkeit in Deutschland. Nürnberg: GPM Deutsche Gesellschaft für Projektmanagement e. V. Retrieved May 8, 2018 from https://www.gpm-ipma.de/fileadmin/user_upload/KnowHow/studien/GPM_Studie_Vermessung_der_Projektt\%C3\%A4tigkeit.pdf.

\section{Authors}

\section{Prof. Daniel Seelhofer, PhD}

Director, Department of International Business

Zurich University of Applied Sciences

School of Management and Law

Zurich, Switzerland

seda@zhaw.ch

\section{Christian Olivier Graf, MSc.}

Lecturer of international project management

Zurich University of Applied Sciences

School of Management and Law

Zurich, Switzerland

grac@zhaw.ch 